\title{
Giant cell tumours in mandible and spine: a rare complication of Paget's disease of bone
}

\author{
M Bhambhani, B G H Lamberty, M R Clements, S J Skingle, A J Crisp
}

\begin{abstract}
The case of a man who was diagnosed as having polyostotic Paget's disease at the age of $\mathbf{5 2}$ years is described. He developed a rare neoplastic complication of Paget's disease-a giant cell tumour in his mandible, which was excised. Nine years after the diagnosis of this tumour he developed a new giant cell tumour arising from the $\mathbf{L} 3$ vertebral body. He was born in Avellino in Italy, from where five other cases of giant cell tumours arising from Pagetic bone disease have been reported. No family relationship between our patient and the other cases was established. His Paget's disease was particularly aggressive and resistant to treatment with two single high dose infusions of pamidronate almost two years apart.
\end{abstract}

(Ann Rheum Dis 1992; 51: 1335-1337)

The development of malignant osteosarcoma is a well known but rare complication of Paget's disease, ${ }^{1}$ and it is often assumed that all neoplastic transformations in Paget's disease are malignant and universally fatal. Giant cell tumour is an even rarer complication of Paget's disease. $^{2}$

\section{Case report}

A man born in 1925 in Avellino near Naples in Italy was referred to Addenbrooke's Hospital in 1980 with a three year history of widespread Paget's disease affecting his skull, jaw, cervical and thoracic vertebrae, ribs, femora, and proximal tibiae. He complained of generalised musculoskeletal pains, headaches, tinnitus, and deafness. He had previously worked in Belgian coalmines but was now employed as a machine operator in England. He had had a duodenal ulcer in 1962 but had otherwise been well. There was no recorded family history of Paget's disease or bone tumours.

Examination showed skull enlargement, a dorsal kyphosis, and bilateral sensorineural deafness.

Investigations showed normal blood urea, creatinine, electrolytes, and glucose; serum calcium $2 \cdot 37 \mathrm{mmol} / 1$ (normal range $2 \cdot 2-2 \cdot 6$ ), phosphate $1.22 \mathrm{mmol} / \mathrm{l}(0.8-1 \cdot 4)$, and serum alkaline phosphatase 1410 IU/l (30-135). Radiography showed Paget's disease in the skull vault with basilar invagination, in several vertebral bodies, pelvis, ribs, femora, and tibiae.

He was unable to tolerate salcatonin 100 units daily. He then complained of pain in his teeth and lower jaw, and radiography showed typical Pagetic changes in the mandible. Treatment with etidronate $400 \mathrm{mg}$ daily, calcium, and vitamin $\mathrm{D}(25 \mu \mathrm{g}$ calciferol) was started. His serum alkaline phosphatase level before treatment was $1690 \mathrm{IU} / \mathrm{l}$. After six months' treatment this level had fallen to 369 IU/1 but with only a modest improvement in his symptoms. Within three weeks of stopping treatment the serum alkaline phosphatase level had risen again to $1150 \mathrm{IU} / \mathrm{l}$. A second course of etidronate was given with a nadir of alkaline phosphatase of $347 \mathrm{IU} / \mathrm{l}$. He then had two courses of mithramycin ( $15 \mu \mathrm{g} / \mathrm{kg}$ daily for five days per course), with improvement in his symptoms, followed by combinations of treatment with etidronate $400 \mathrm{mg}$ daily and salcatonin 100 units daily, covered by pizotifen ( $1.5 \mathrm{mg}$ daily) to reduce side effects. ${ }^{3}$ He was then able to tolerate salcatonin but continued to have severe lower jaw pain. After this he developed an ulcerating mandibular swelling with loosening of the lower four incisors (fig 1). The mass was biopsied and

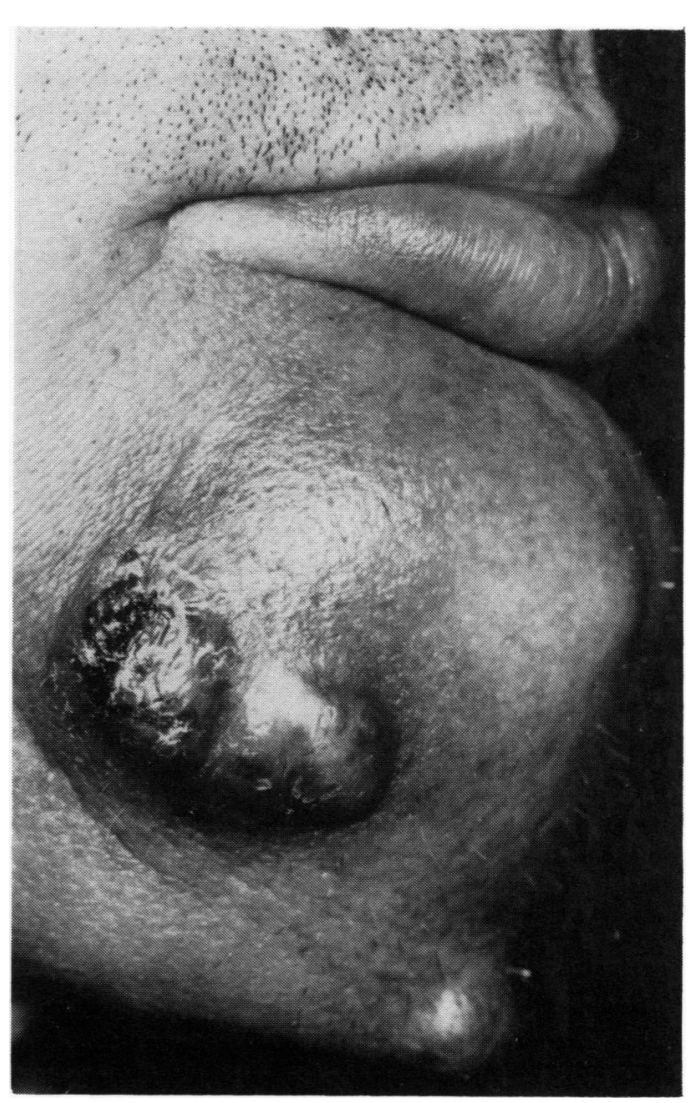

Figure 1 This shows a mandible expanded by the tumour mass which has ulcerated through the skin. 
then curetted in 1982. Histological examination showed a mass of closely packed multinucleated giant cells of variable size and nuclear number consistent with the diagnosis of benign giant cell tumour (fig 2). Electron microscopy of the giant cell nuclei showed paramyxovirus-like inclusion

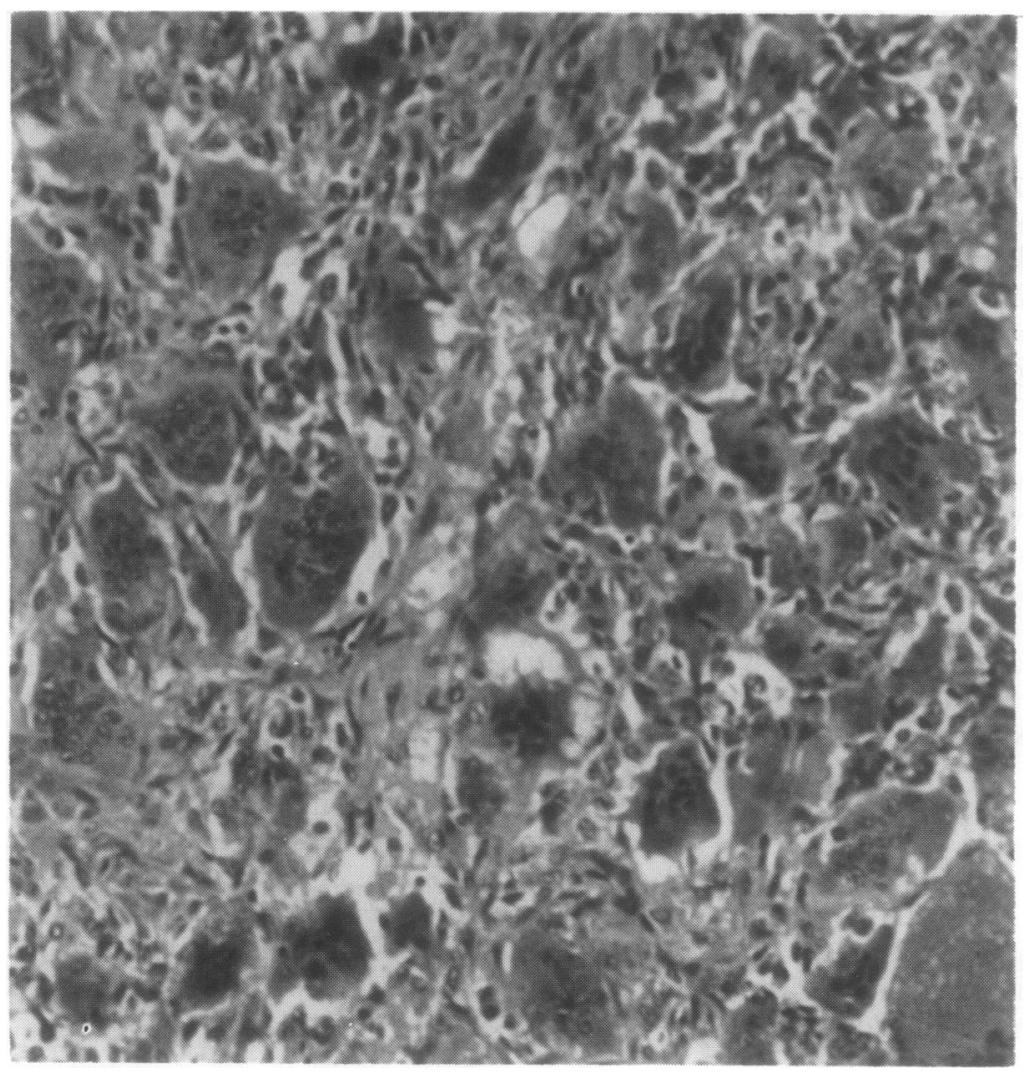

Figure 2 The histology of the giant cell tumour arising from Pagetic bone. Note the connective tissue containing a mass of closely packed multinucleate cells of different sizes.

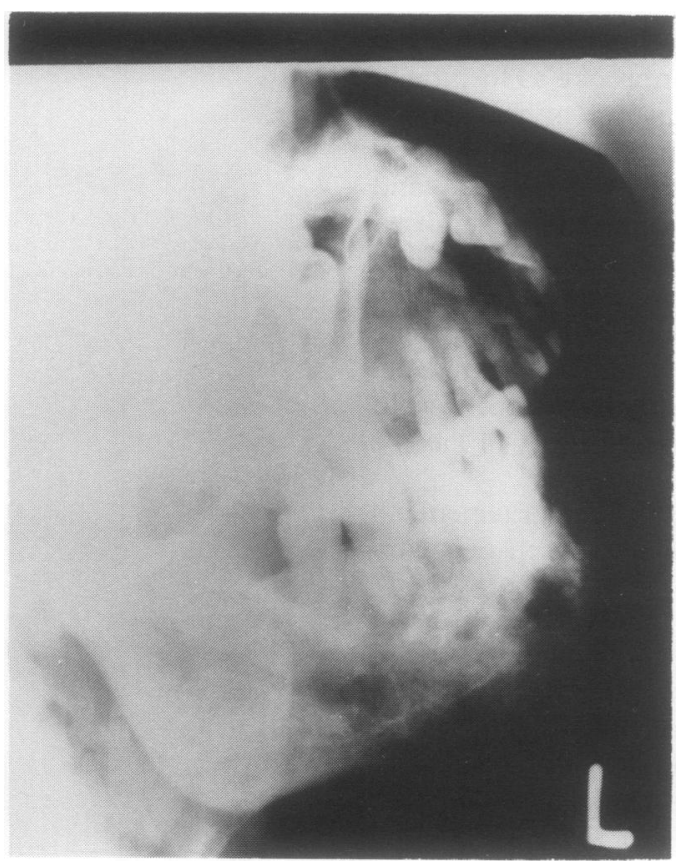

Figure 3 A radiograph of the mandible showing lytic lesions and bony erosion. bodies. Treatment with etidronate and salcatonin continued with the lowest value of serum alkaline phosphatase so far achieved of $329 \mathrm{IU} / \mathrm{l}$.

About six months later a further swelling of the mandible appeared and was again curetted. The tumour was noted to have invaded striated muscle. Curettage was incomplete and the tumour mass again expanded. This reduced in size with dexamethasone, but in 1983 the mandible was irradiated ( $45 \mathrm{~Gy}$ in 15 fractions over five weeks), with almost complete resolution of the mass. About one year later the tumour recurred. A computed tomographic scan showed destruction of the mandible and muscle infiltration which spread down to the thyroid cartilage without infiltrating it (fig 3). The tumour was then excised and included the floor of the mouth, the gingival margin, and the whole of the mandible from the second molar forwards on each side. Reconstruction was carried out with an osteocutaneous radial forearm flap (BGHL). After this procedure there was still a shortage of bone and a further free osteocutaneous flap was subsequently required, again using skin paddle to allow further insertion of skin into the floor of the mouth. There was no evidence of tumour recurrence at this procedure.

Since these surgical procedures he has had no tumour recurrence in the mandibular region, but in 1985 widespread musculoskeletal pain arising from Pagetic disease of bone again became disabling. A bone scintigram showed increased uptake in skull, spine, ribs, right hemipelvis, and left femur. The 24 hour whole body retention of methylene diphosphonate was considerably raised at $74 \%$ (normal $<40 \%$ ). There was a poor clinical response to further courses of etidronate, and in 1988 he was admitted for a single infusion of $105 \mathrm{mg}$ intravenous pamidronate (3-amino-1-hydroxypropylidene-1,1-bisphosphonate) given over 24 hours in 1 litre of $5 \%$ dextrose. 5 The serum alkaline phosphatase level before treatment was $1290 \mathrm{IU} / \mathrm{l}$, but three months after this treatment it had fallen to $64.3 \%$, and the urine hydroxyproline/creatinine ratio to $60 \%$, of the values before treatment. There was considerable improvement in skeletal pain for about one and a half years when there was symptomatic and biochemical deterioration.

He was readmitted for a second single infusion of pamidronate $105 \mathrm{mg}$ almost two years after the first treatment. Over the next three months the impressive reduction in the hydroxyproline/ creatinine ratio noted after the first treatment was not reproduced but serum alkaline phosphatase fell to $570 \mathrm{IU} / \mathrm{l}$. Nine years after the diagnosis of his mandibular giant cell tumour he developed a right L4 nerve root lesion, and investigations disclosed a new giant cell tumour arising from the $\mathrm{L} 3$ vertebral body. He received a course of radiotherapy, which abolished his back pain with resolution of his right L4 nerve root lesion. Four months after radiotherapy his back tumour recurred, but complete surgical excision of the tumour was technically impossible.

His tissue type was HLA-A1, A3, B12 (Bw44), B17, Bw4, DR1, DR7. 


\section{Discussion}

Giant cell tumour complicating Paget's disease was first described in $1931,{ }^{6}$ and since then about 55 cases have been reported. ${ }^{27-13}$ It usually occurs in patients with severe Paget's disease and typically presents as a non-tender mass in the skull or facial bones, less commonly in the remaining axial skeleton, and rarely in arms and legs. ${ }^{813}$ Symptoms arise from local tumour encroachment, ${ }^{8}$ and patients may present with epistaxis and nasal obstruction with maxillary tumours. ${ }^{2}$

Our patient's first giant cell tumour was diagnosed five years after the diagnosis of Paget's disease. In the series of Hutter et al ${ }^{2}$ the diagnosis of giant cell tumour usually coincided with that of Paget's disease. Patients developing malignant osteosarcoma typically have a long preceding history of the disease. ${ }^{2}$

Malignant sarcomata sometimes have abundant giant cells and can mimic giant cell tumours. Sarcomata typically have more osteoid tissue among the malignant cells than giant cell tumours. $^{2}$ Histological distinction is clearly crucial for prognosis. The presence of virus-like inclusions in osteoclastic nuclei in giant cell tumours occurring in Paget's disease has been previously reported. ${ }^{9} 11$ Although local recurrence after treatment is common, metastasis is very uncommon. ${ }^{8}$

The treatment of giant cell tumour in Paget's disease is often difficult. Small lesions may be curetted, but larger ones require resection. Glucocorticoids may cause some clinical and biochemical improvement, ${ }^{8}$ and mithramycin can cause some tumour regression. ${ }^{8}$ Pearlman and Friedman treated two patients with radiotherapy alone. ${ }^{12}$ Our patient's mandibular tumour was cured only by excision surgery and jaw reconstruction.

A particular feature of interest in our patient is his origin from Avellino in Italy. Jacobs et al described five cases of giant cell tumour in Paget's disease of bone in patients, all of whom originated from Avellino. ${ }^{8}$ Our patient has relatives in Avellino, including a doctor, but we have been unable to establish any links between the families reported by Jacobs et al and our patient's family. Multiple giant cell tumours occurring in the same patient must be exceedingly rare, though one patient developed 27 similar tumours. 8
We have also reported the response of our patient's widespread active Paget's disease to a single infusion of high dose pamidronate. ${ }^{14}$ The $105 \mathrm{mg}$ dose we used gave good relief of Pagetic pain and some lowering of the serum alkaline phosphatase level. This dose typically achieves an excellent clinical and biochemical remission in uncomplicated Paget's disease and has become our treatment of first choice. ${ }^{5}$ Our patient's nadir value of serum alkaline phosphatase was $570 \mathrm{IU} / \mathrm{l}$, indicating his relative biochemical resistance to this regimen.

\section{Addendum}

One year after the development of the L3 vertebral body giant cell tumour, a third giant cell tumour has been located in the nasal cavity invading erythroid air cells and frontal sinuses.

We thank Mrs Carol Phillips for typing this manuscript.

1 Barry H C. Paget's disease of bone. Edinburgh and London: E \& S Livingstone, 1969: 136-77.

2 Hutter R V P, Foote F W, Frazell E L, Francis K C. Giant cell tumours complicating Paget's disease of bone. Cancer 1963; 16: 1044-56.

3 Crisp A J. Pizotifen to prevent side effects of calcitonin. Lancet 1980; i: 775 .

4 Fogelman I, Bessent R G, Turner J G, Citrin D L, Boyle I T, Greig $W R$. The use of whole body retention of $99 \mathrm{~m}$ diphosphonate in the diagnosis of metabolic bone disease. diphosphonate in the diagnosis

5 Bhambhani M, Skingle S J, Watts R A, Pountain G, Crisp A J. Effect of single infusion of pamidronate on Paget's disease of bone. $\mathrm{Br} \mathcal{Y}$ Rheumatol 1991; 30 (suppl 2): 95.

6 Hunter D, Turnbull H M. Hyperparathyroidism: generalised osteitis fibrosa with observations upon bones, parathyroid tumours and normal parathyroid glands. Brf Surg 1931-32; 19: 203-84

7 Goldenberg R R, Campbell C J, Bonfiglio M. Giant cell tumour of bone. An analysis of 218 cases. $\mathcal{F}$ Bone foint Surg [Am] 1970; 52: 619-64.

8 Jacobs T P, Michelsen J, Polay J S, D'Adamo A C, Canfield R E. Giant cell tumour in Paget's disease of bone. Familial and geographical clustering. Cancer 1979; 44: 742-7.

9 Mirra J M, Bauer F C, Grant T T. Giant cell tumour with viral like intranuclear inclusions associated with Paget's disease. Clin Orthop 1981; 158: 243-51.

10 Miller A S, Cuttino C L, Elzay R P, Levy W M, Harwick R D. Giant cell tumour of the jaw associated with Paget's $\mathrm{R} D$. Giant cell tumour of the jaw associated with Page
disease of bone. Arch Otolaryngol 1974; 100: 233-6.

11 Carles D, Rivel J, Devars F, et al. Giant cell tumours developing in Paget's disease. Presentation of 2 cases with an ultrastructural study. Ann Pathol 1989; 9: 47-53.

12 Pearlman A W, Friedman M. Radiation therapy of benign giant cell tumour arising in Paget's disease of bone. Isoeffect recovery study. Am $\mathcal{F}$ Roentgenol 1968; 102: 645-51.

13 Levine H A, Enrile F. Giant cell tumour of patellar tendon coincident with Paget's disease. $\mathcal{F}$ Bone foint Surg [Am] 1971; 53: 335-40.

14 Thiebaud D, Jaeger P, Goblet C, Jacquet A F, Burckhardt P. A single infusion of the biphosphonate AHPrB.P (APD) as treatment of Paget's disease of bone. Am F Med 1988; 85: 207-12. 